\title{
The Effects of Cobalt Deficiency on the Appetite of Lambs
}

\author{
BY J. STEWART \\ Moredun Institute, Gilmerton, Edinburgh, 9
}

(Received 31 October 1952)

In a previous paper Das \& Stewart (1950) showed by measuring the faecal excretion of groups of lambs grazing cobalt-dressed and cobalt-deficient pasture that the lambs grazing the cobalt-deficient pasture did not eat as much as those grazing the pasture top-dressed with cobalt. The authors suggested that the clinical signs of cobalt deficiency in lambs, i.e. marasmus, might all be due to the low food intake and that the low intake might be due to the low cobalt content of the food interfering with the physiological controls of appetite. The experiments described in this paper were designed to test this suggestion.

\section{EXPERIMENTAL}

\section{First experiment, 1949-50}

Stewart (195I) showed that cobalt deficiency could be induced in lambs if their mothers were fed on a daily diet consisting of $\mathrm{I}$ roo $\mathrm{g}$ flaked maize, $25^{\circ} \mathrm{g}$ hay and $60 \mathrm{~g}$. mineral mixture during the last 3 months of pregnancy, which allowed of daily ingestion of $0.0687 \mathrm{mg}$ cobalt, and if at weaning at ro weeks of age the lambs were given daily $800 \mathrm{~g}$ flaked maize, $80 \mathrm{~g}$ hay and $25 \mathrm{~g}$ mineral mixture $(0.0347 \mathrm{mg}$ cobalt) increasing steadily to the quantities in the ewes' diet at 16 weeks of age. Lambs given the basal diet supplemented with Io mg cobalt weekly from birth all gained weight normally.

In the present experiments use was made of this diet, and the same procedure was adopted in feeding and management as described in the previous paper (Stewart, I95I). Six lambs, all born within Io days of each other, and from ewes that had received the basal diet for the last 3 months of pregnancy, were selected, and four lambs, A, B, C, D, were given $10 \mathrm{mg}$ cobalt weekly from birth, while two, E and F, received no cobalt supplement. The lambs were weaned at 8 weeks of age. Lambs $E$ and $\mathrm{F}$ were offered $800 \mathrm{~g}$ flaked maize, $80 \mathrm{~g}$ hay and $25 \mathrm{~g}$ mineral mixture daily. An assay of the ration showed that the diet contained $0.035 \mathrm{mg}$ cobalt. The ration was. weighed out accurately daily and the next morning all residues were weighed. Lamb $\mathrm{C}$ was fed exactly the amount of each foodstuff that lamb $\mathrm{E}$ had eaten the previous day and lamb $\mathrm{D}$ the same as lamb $\mathrm{F}$ had eaten the previous day. Thus $\mathrm{E}$ and $\mathrm{C}$, and $F$ and D became pairs of lambs receiving the same diet as far as energy constituents. were concerned, but the weekly cobalt supplement given to lambs $\mathrm{C}$ and $\mathrm{D}$ since birth was continued. Lambs A and B were offered the same rations as lambs $E$ and F, but the quantity was regulated to their appetite and their cobalt supplement was also continued. The amount of ration offered to lambs E, F, A and B was gradually 
increased over the period of the experiment. The experiment was continued thus for 15 weeks. At this stage, when the lambs were 23 weeks of age, C and D were allowed to consume the basic ration to the limit of their appetite and $\mathrm{E}$ and $\mathrm{F}$ were given $10 \mathrm{mg}$ cobalt weekly.

\section{Second experiment, 1950-1}

The experiment was repeated in $195^{\circ-1}$, six lambs, M, N, P, Q, R, S, being selected at birth and the same experimental and dietary procedure adopted as in 1949-50. After weaning at 8 weeks of age, lambs $P$ and $Q$, which had received a weekly supplement of Io mg cobalt from birth, were restricted in diet to exactly what had been eaten the previous day by lambs $R$ and $S$, respectively. Thus $P$ and $R$, and $Q$ and $S$ became pairs of lambs receiving the same diet as far as energy constituents were concerned but, in addition, $\mathrm{P}$ and $\mathrm{Q}$ received $10 \mathrm{mg}$ cobalt weekly. Lambs $\mathrm{M}$ and $\mathrm{N}$ acted as controls, receiving cobalt supplement from birth and at weaning being given the same ration as that offered to lambs $R$ and $S$, the quantity being regulated by their appetite. This procedure of feeding was continued for 8 weeks, when lambs $R$ and $S$ were given a weekly supplement of $10 \mathrm{mg}$ cobalt and lambs $\mathrm{P}$ and $\mathrm{Q}$ allowed the basal diet to the limit of their appetite.

RESULTS

The live-weight curves of the six lambs A, B, C, D, E and F are shown in Fig. I and the live-weight curves of lambs M, N, P, Q, R and S are shown in Fig. 2.

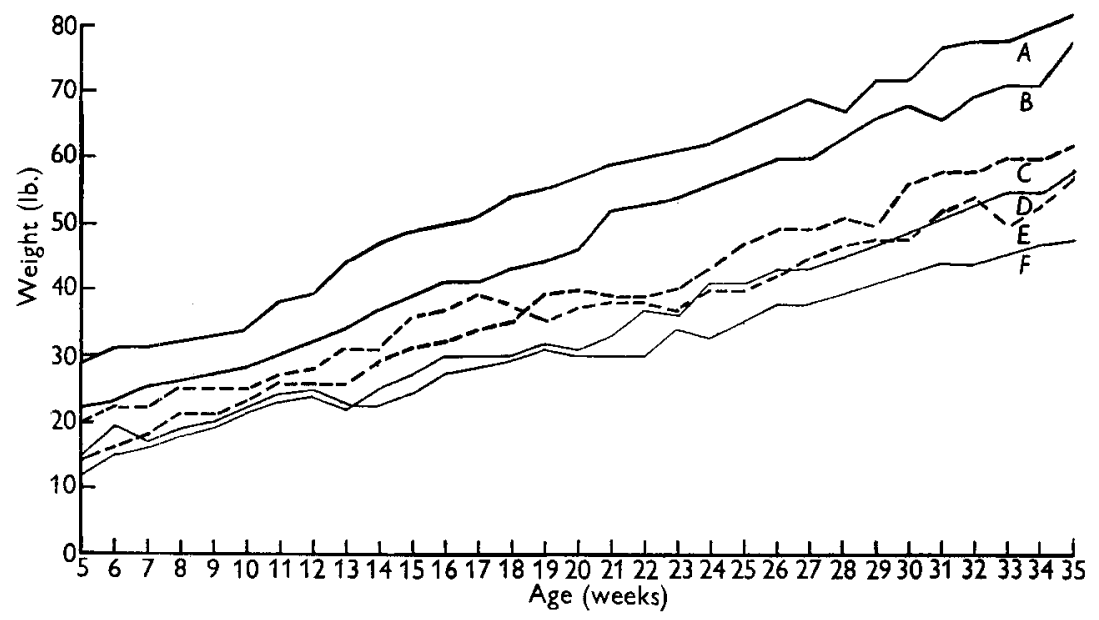

Fig. I. Live-weight curves of lambs, A, B, C, D, E and F in the 1949-50 experiment. $\longrightarrow$ - lambs $\mathrm{C}$ and $\mathrm{E}$; $\longrightarrow$, lambs $\mathrm{A}$ and $\mathrm{B}$; —, lambs $\mathrm{D}$ and $\mathrm{F}$.

The live-weight curves of the control lambs A, B, M, N in both experiments were similar to those obtained in previous experiments on similar diets (Stewart, 1951) and in field experiments (Stewart, 1946), this showing that the basal diet contained sufficient starch and protein equivalent for normal growth, provided sufficient cobalt was given as a supplement. 
Lambs $\mathrm{C}$ and $\mathrm{D}$ during the 15 weeks they were receiving exactly the same diet as lambs $\mathrm{E}$ and $\mathrm{F}$, respectively, made similar, almost identical, live-weight gains to those of lambs $\mathrm{E}$ and $\mathrm{F}$, and at the end of the 15 th week all four lambs showed a significantly lower live weight than the control lambs A and B. The difference in live-weight gain was in keeping with the difference between food ingested, since by the ${ }_{5} 5^{\text {th }}$ week lambs $A$ and $B$ were ingesting over $\mathrm{r}_{4} \mathrm{lb}$. of the ration/week, whereas lambs $\mathrm{E}$ and $\mathrm{F}$ (and consequently $\mathrm{C}$ and $\mathrm{D}$ ) were eating only about $8 \mathrm{lb}$./week. It will be seen from Fig. I that as soon as lambs $\mathrm{E}$ and $\mathrm{F}$ were given the cobalt supplement (i.e. at 23 weeks) and lambs $\mathrm{C}$ and $\mathrm{D}$ were allowed an unrestricted diet all four lambs began to make substantial live-weight gains, with lambs $\mathrm{C}$ and $\mathrm{D}$ making larger gains than $\mathrm{E}$ and $\mathrm{F}$. This again was a reflexion of the amount of food eaten, since lambs $\mathrm{C}$ and $\mathrm{D}$ quickly

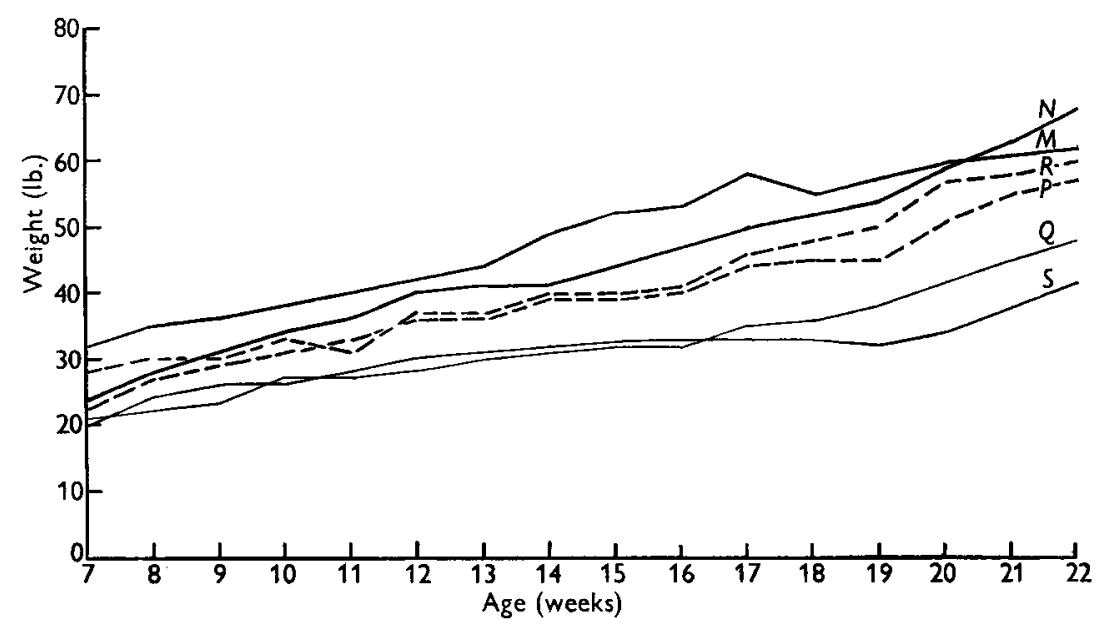

Fig. 2. Live-weight curves of lambs $M, N, P, Q, R$ and $S$ in the $195^{\circ-1}$ experiment. --- , lambs $\mathrm{P}$ and $\mathrm{R} ;-$, lambs $\mathrm{M}$ and $\mathrm{N} ;-$, lambs $\mathrm{Q}$ and $\mathrm{S}$.

increased their consumption to $\mathrm{I} 2 \mathrm{lb}$./week, whereas lambs $\mathrm{E}$ and $\mathrm{F}$ gradually increased their intake to between ro and I $\mathrm{lb}$.

In the second experiment the live-weight gains of lambs $P$ and $Q$ followed very closely those of lambs $\mathrm{R}$ and $\mathrm{S}$ from the 8th to the $\mathrm{i}$ th week, lambs $\mathrm{P}$ and $\mathrm{Q}$ making a gain in live weight of $I_{3}$ and ro $l b$., respectively, whilst lambs $R$ and $S$ increased in weight by $\mathrm{II}$ and $9 \mathrm{lb}$., respectively, in the 8 weeks. The control lambs $\mathrm{M}$ and $\mathrm{N}$ in the same period made live-weight gains of 18 and $20 \mathrm{lb}$., respectively. As in the first experiment, once lambs $P$ and $Q$ were allowed an unrestricted diet they quickly increased their weight, adding 19 and $18 \mathrm{lb}$., respectively, in 7 weeks. When at the I6th week lamb $\mathrm{R}$ was given a cobalt supplement it also made a rapid increase in live weight, adding $23 \mathrm{lb}$. in 7 weeks. Lamb S, however, though given a cobalt supplement from the 16 th week, continued at a constant weight for another 3 weeks before beginning to increase in weight, but added ${ }_{5} \mathrm{lb}$. in the next 4 weeks. 
DISCUSSION

From the results detailed above it is shown that the live weights of lambs $\mathrm{C}, \mathrm{D}, \mathrm{P}$ and $\mathrm{Q}$ were determined by the amount of food eaten by lambs E, F, R and S, and that the cobalt supplement given to $\mathrm{C}, \mathrm{D}, \mathrm{P}$ and $\mathrm{Q}$ did not help to increase the efficiency of digestion of their diet, as far as can be interpreted by live-weight increases. Since each pair of lambs, $C$ and E, D and F, P and R, Q and S, showed similar live-weight increases, despite one member of each pair receiving cobalt, it would appear that the addition of cobalt to a cobalt-deficient diet did not in itself increase the energy value of the ration by either stimulating metabolism or making the energy-promoting constituents of the ration more available to the animal. The live-weight increases of lambs $\mathrm{A}, \mathrm{B}, \mathrm{M}$ and $\mathrm{N}$ were those of normal animals on a diet of equal starch and protein equivalent. Therefore the live-weight increases of lambs $\mathrm{C}, \mathrm{D}, \mathrm{P}$ and $\mathrm{Q}$ were restricted by the amount eaten and not by the cobalt content of their ration, since they were receiving the same cobalt supplement as lambs $A, B, M$ and $N$. As the restriction of the amount they ate was enforced by the amount eaten by lambs E, F, R and S, which received no cobalt supplement, and as lambs $E, F, R$ and $S$ at 8 weeks of age were offered the same ration as $\mathrm{A}, \mathrm{B}, \mathrm{M}$ and $\mathrm{N}$, it must be concluded that the cobalt content of the ration of lambs E, F, R and $S$ influenced the amount of the ration ingested by these lambs and consequently their live-weight increase. In other words, the low cobalt content of their ration seriously affected the appetites of lambs E, F, R and S, and this in turn accounted for the poor live-weight increase and the obvious clinical signs of marasmus in these animals.

The factors affecting the appetite of a ruminant animal are unknown, but it is possible that, if microbial digestion in the rumen is inefficient and the passage of food from the rumen to abomasum slowed down because of the overfullness of the rumen, the animal would be disinclined to eat. This view would be in accordance with the commonly accepted role of cobalt in ruminant physiology, namely, that cobalt is necessary in the rumen for the optimum growth of microflora and, consequently, for the optimum breakdown of feeding-stuffs in the rumen and for the passage of the breakdown products along the alimentary tract.

\section{SUMMARY}

I. Four sets of paired lambs were fed on a cobalt-deficient ration composed of flaked maize, hay and a mineral mixture containing the known essential minerals other than cobalt. One of each pair received a cobalt supplement of $10 \mathrm{mg}$ cobalt weekly, but was restricted in its diet to the exact amount of the ration that the other member of the pair had eaten the previous day.

2. Each pair of lambs made almost identical live-weight gains during the period under experiment, and these gains were in keeping with those of cobalt-deficient lambs and very much less than those of other lambs given the basal diet in unrestricted amounts, but given a cobalt supplement.

3. It was concluded that cobalt deficiency restricts the appetite of lambs and that the restricted appetite is the cause of marasmus, the clinical syndrome of cobalt 
Through the generosity of a number of commercial firms and private people the Proceedings of the Lind Bicentenary Meeting, held in Edinburgh on 22 and 23 May 1953, will be published shortly as an additional number of the Proceedings of The Nutrition Society, no. 3 of volume 12. It will contain papers by $\mathrm{H}$. Chick, J. H. Crandon, W. J. Darby, W. J. McGanity \& C. W. Woodruff, S. F. Dudley, J. P. Dustin \& E. J. Bigwood, R. C. Garry, H. Gounelle \& H. Teulon, L. J. Harris, A. Ingleby-Mackenzie, F. A. Isherwood, R. M. Kark, C. G. King, H. A. Krebs, A. J. Lorenz, L. W. Mapson, C. P. Stewart, D. B. Horn \& J. S. Robson, V. P. Sydenstricker, M. van Eekelen and S. B. Wolbach.

This number will be supplied free to members of the Society and subscribers to the Society's publications. Copies will be available to others at $f_{2}$. os. od. ( $\$ 7.5^{\circ}$ in U.S.A.) plus postage. Orders for these should be placed at once with a bookseller or sent direct to Cambridge University Press, Bentley House, 200 Euston Road, London, N.W. I, or, American Branch, 32 East 57th Street, New York 22. 
deficiency. Moreover, since a cobalt supplement did not enhance live-weight gains at the level of food intake of the cobalt-deficient lambs, the increase in live weight that occurred when lambs on an unrestricted cobalt-deficient diet received a cobalt supplement must have been due to an increased consumption of food, that is, to an increase in the appetite of the lambs.

4. The bearing of this finding on the physiological role of cobalt in ruminants is briefly discussed.

\title{
REFERENCES
}

Das, P. K. \& Stewart, J. (I950). Emp. F. exp. Agric. 18, I I2.

Stewart, J. (1946). Scot. Agric. 26, 6.

Stewart, J. (I95I). Brit. F. Nutr. 5, 320.

\section{Autoradiographic Study of Growth and Calcium Metabolism in the Long Bones of the Rat}

\author{
By D. H. TOMLIN \\ Department of Physics, University of Reading \\ AND KATHLEEN M. HENRY AND S. K. KON \\ National Institute for Research in Dairying, University of Reading \\ (Received 20 November 1952)
}

It is well known that skeletal growth is influenced by nutrition, but detailed knowledge of the effects is by no means complete. We are of the opinion that long-term experiments covering an appreciable part of the life span of the experimental animal are best suited for the study of bone growth and development, and we have already published results of metabolic studies carried out under such conditions (Henry \& Kon, I947, I953).

Apart from metabolic tests, use of tracer substances is perhaps the most satisfactory method of studying bone growth in detail. Tracers that have been used in this way fall into two classes: ( $x$ ) organic dyes that, when taken with the food or injected into the circulation, form coloured bone salts and thus label new bone material, and (2) radioactive isotopes of the elements that participate in bone formation. The classic experiments of Hunter (1837) and the work of Brash (1934 $a, b)$ and Payton (1932), in which madder was given to growing pigs, are examples of the first method. Radioactive phosphorus, ${ }^{32} \mathrm{P}$, has been used by many workers in studying various aspects of skeletal metabolism. Autoradiography of bone sections from animals that have received a radioactive tracer reveals the distribution of labelled element in the section. A comprehensive account of this technique, with an extensive bibliography, has been published by Bourne (1952). The autoradiographic technique with ${ }^{32} \mathrm{P}$ has 